\title{
Electrical conductivity and somatic cell count in zebu cow's milk
}

\section{Condutividade elétrica e contagem de células somáticas do leite de vacas zebuínas}

\author{
Emmanuella de Oliveira Moura ${ }^{1}$; Adriano Henrique do Nascimento Rangel²; \\ Luis Henrique Fernandes Borba²; José Geraldo Bezerra Galvão Júnior ${ }^{3}$; \\ Guilherme Ferreira da Costa Lima'; Dorgival Morais de Lima Júnior ${ }^{5}$; \\ Gelson dos Santos Difante ${ }^{2}$; Stela Antas Urbano ${ }^{2 *}$; Emerson Moreira de Aguiar ${ }^{2}$
}

\begin{abstract}
The objective was to evaluate the physico-chemical composition, somatic cell count and electrical conductivity of the milk from lactating Zebu cows. For this, monthly milk samples were collected on the official milk control day intended for analysis of electrical conductivity of milk (ECM), somatic cell count (SCC) and milk composition. We used monthly data from 680 controls, from 10 Gyr and 17 Guzerat cows from a herd located in the city of São Gonçalo do Amarante/RN, from August to November 2013. Analyses of variance, mean test and Pearson correlation analysis were conducted. The levels of fat $(\% \mathrm{~F})$, protein $(\% \mathrm{P})$, lactose $(\% \mathrm{~L})$, total solids $(\% \mathrm{TS})$ and non-fat dry extract $(\% \mathrm{NFDE})$ were dependent variables for the ECM and SCC. The milk of Gyr cows for ECM, SCC, GOR, PROT, LACT, TS and NFDE were respectively, $3.88 \pm 1.18 \mathrm{mS} / \mathrm{cm}, 1629 \pm 2195$ thousands cells $/ \mathrm{mL}, 4.71 \pm 1.77 \%$, $3.29 \pm 0.31 \%, 4.5 \pm 0.33 \%, 13.5 \pm 1.78 \%, 8.79 \pm 0.37 \%$, and for the Guzerat breed $3.59 \pm 0.88 \mathrm{mS} / \mathrm{cm}$ $1356 \pm 1793$ thousands cells $/ \mathrm{mL}, 4.47 \pm 0.98 \%, 3.43 \pm 0.32 \%, 4.52 \pm 0.24 \%, 13.5 \pm 1.19 \%, 9.02 \pm 0.48 \%$. No significant correlations between SCC and ECM characteristics were observed. However, when the correlation of each of these parameters and milk composition in different classes for each breed was analyzed, a significant correlation of the SCC was observed with the protein and lactose in Gyr, of the ECM with the lactose and SCC with total solids and fat for the Guzerat cows.
\end{abstract}

Key words: Composition. Mastitis. Milk production.

\section{Resumo}

O objetivo foi avaliar a composição físico-química, contagem de células somáticas e condutividade elétrica do leite de fêmeas zebuínas. Para isto, foram coletadas amostras mensais de leite no dia do controle leiteiro oficial, sendo elas destinadas às análises de Condutividade Elétrica do Leite (CEL), contagem de células somáticas (CCS) e composição do leite. Foram utilizados 680 dados de controles mensais, provenientes de 10 vacas da raça Gir e 17 da raça Guzerá, pertencentes a um rebanho localizado na cidade de São Gonçalo do Amarante/RN, no período de agosto a novembro de 2013. Realizou-se

1 Zootecnista, M.e em Produção Animal, Programa de Pós-graduação em Produção Animal, UFRN, Unidade Acadêmica Especializada em Ciências Agrárias, Macaíba, RN, Brasil. E-mail: manu moura9@yahoo.com.br

2 Profs., Universidade Federal do Rio Grande do Norte, UFRN, Unidade Acadêmica Especializada em Ciências Agrárias, Macaíba, RN, Brasil.E-mail: adrianohrangel@yahoo.com.br; lborba99@yahoo.com; gdifante@hotmail.com; stela_antas@yahoo.com.br; emersonmaguiar@gmail.com

3 Prof., Instituto Federal de Educação, Ciência e Tecnologia Rio Grande do Norte, IFRN, Ipanguaçu, RN, Brasil. E-mail: geracari@ yahoo.com.br

4 Pesquisador, Empresa Brasileira de Pesquisa Agropecuária, EMBRAPA, Empresa de Pesquisa Agropecuária do Rio Grande do Norte, EMPARN, Natal, RN, Brasil. E-mail: guilhermeemparn@rn.gov.br

5 Prof., Universidade Federal de Alagoas, UFAL, Campus Arapiraca, Arapiraca, AL, Brasil. E-mail: juniorzootec@yahoo.com.br

* Author for correspondence 
análise de variância, teste de média e análise de correlação de Pearson. Como variáveis dependentes a CEL e CCS, estavam os teores de gordura $(\% \mathrm{G})$, proteína $(\% \mathrm{P})$, lactose $(\% \mathrm{~L})$, sólidos totais $(\% \mathrm{ST})$ e extrato seco desengordurado (\%ESD). Ao serem analisadas médias da raça Gir para CEL, CCS, GOR, PROT, LACT, ST e ESD foram, respectivamente, 3,88 $\pm 1,18 \mathrm{mS} / \mathrm{cm}, 1629 \pm 2195$ mil cels. $/ \mathrm{mL}$, $4,71 \pm 1,77 \%, 3,29 \pm 0,31 \%, 4,5 \pm 0,33 \%, 13,5 \pm 1,78 \%, 8,79 \pm 0,37 \%$, e para a raça Guzerá, $3,59 \pm 0,88 \mathrm{mS} /$ cm 1356 \pm 1793 mil cels. $/ \mathrm{mL}, 4,47 \pm 0,98 \%, 3,43 \pm 0,32 \%, 4,52 \pm 0,24 \%, 13,49 \pm 1,19 \%, 9,02 \pm 0,48 \%$. Não foram verificadas correlações significativas entre as características CCS e CEL. Porém, quando feito a correlação de cada um destes parâmetros com a composição do leite em diferentes classes para cada raça, foi observado, correlação significativa da CCS com a proteína e lactose na raça Gir, da CEL com a lactose e CCS com gordura e sólidos totais para os animais da raça Guzerá.

Palavras-chave: Composição. Mastite. Produção de leite.

\section{Introduction}

Milk is a high value organic food and an important source of protein and fat in the human diet that can be consumed raw or processed. However, it's not only the processing of milk but also the whole logistical process of milk which is subject to a number of hygiene and sanitary control standards to ensure that the product is free of micro-organisms or other potentially harmful substances to human health (LANGONI, 2013).

Among the practices intended to ensure the quality of milk is hygienic milking; a set of practices put in place for reducing the contamination of milk and cow's udder during milking. The contamination of the udder is followed by the development of an infection resulting in mastitis. Mastitic milk presents a series of changes in its physical and chemical composition. This change can influence throughput processing, cause losses and increase industrial production costs (BARBANO et al., 2006; LANGONI et al., 2011; SHARMA et al., 2011; RIBEIRO NETO et al., 2012).

The somatic cell count (SCC) is a monitoring tool for measuring infection of the mammary gland. It correlates with mastitis and provides an estimate of the impairment of the udder secreting parenchyma (BAVA et al., 2011; BALLOU, 2012). The electrical conductivity of milk (ECM) was introduced as a characteristic indicator of mastitis in the 1970s and has been used since then for the detection of this infection/illness (MABROOK;
PETTY, 2003; NORBERG, 2005; FOSGATE et al., 2013). ECM measures the ability of a solution to conduct an electric current between two electrodes and is usually measured in milliSiemens per centimeter $(\mathrm{mS} / \mathrm{cm})$.

When mastitis is present, the potassium concentration in the milk decreases while the concentrations of sodium and chloride ions increase, leading to increased ECM. The test is based on the principle that an increased ECM is directly proportional to increased udder inflammation and increased SCC. The normal value of ECM for $25^{\circ} \mathrm{C}$ ranges between 4.0 and $55.5 \mathrm{mS} / \mathrm{cm}$ (YOSHIDA et al., 2005).

When compared to conventional mastitis detection techniques, the ECM is obtained more easily, quickly and cost effectively, becoming an important tool to assist in the control of mastitis; especially compared to bacterial identification information or the presence of somatic cells where it is necessary to send samples to a specialized laboratory (RAIMONDO et al., 2009; FOSGATE et al., 2013). The ECM analysis can be performed using portable equipment or from the equipment coupled with the automated milking and as the results are available within seconds after milking, it is therefore very helpful in the early diagnosis of mastitis (UHLER, 2009; KAŞIKÇI et al., 2012).

Given the above, the objective was to relate the levels of electrical conductivity, somatic cell count and chemical composition of milk from Zebu cows. 


\section{Material and Methods}

Data were obtained from Gyr and Guzerat cows from herds raised at Rockefeller Experimental Station, located in São Gonçalo do Amarante RN, which belongs to the Agricultural Research Company of Rio Grande do Norte (EMPARN) and colleting time, from August to November 2013. The Experimental Station is located in the coastal region of Rio Grande do Norte state. The climate was classified as Aw, tropical with a dry season (Köppen-Geiger). The average rainfall in the region during the trial period was approximately 1500 $\mathrm{mm}$ per year, an average temperature of $26^{\circ} \mathrm{C}$, and average relative humidity of $78.0 \%$, according to data obtained from a meteorological station installed on the farm.

The production system is based on 150 ha of pasture in a continuous stocked grazing with individual supplementation with concentrate according to cow production. During the experimental procedures, the herds' diet varied according to time of year; during the rainy season, it was based only on grazing of Brachiaria brizanta or dwarf elephant grass (Pennisetum purpureum Schum.cv. Mott) and in the dry season pasture were supplemented with concentrate mixture, cows also received sorghum silage or corn mixed with elephant grass silage.

Twenty-seven (27) lactating cows, being ten (10) Gyr and 17 Guzerat were selected for using in this experiment, all of pure breed (PO). The lactating cows had varying age, birth order and lactating stages and had average body weight of $470 \mathrm{~kg}$. Milking was done mechanically twice a day, in a high line herringbone type system every twelve hours, at 4:00 $\mathrm{h}$ and 16:00 h. Mastitis control practices were adopted for the whole herd, such as pre-dipping, as well as treatment of dry cows and clinical cases. The post-dipping technique was not applied because at the end of each milking calves were released along with the cows. The calf's presence at milking time was necessary as a stimulus for milk ejection.
Samples were collected monthly in duplicate, provided by composite samples from milking in the morning and afternoon on the milk control day, in universal collectors with $40 \mathrm{~mL}$ capacity, identified with a code and name of the animal, and packed in insulated boxes with ice between $2{ }^{\circ} \mathrm{C}$ and $7^{\circ} \mathrm{C}$. One of the samples was intended to carry out the measurement of electrical conductivity and referred to the Milk Quality Laboratory of UFRN (LABOLEITE). However, another sample containing a Bronopol ${ }^{\circledR}$ preservative tablet of 10 mg (2-bromo 2-nitro-1,3-propanediol) was referred to the Embrapa Milk Quality Analysis Laboratory of Dairy Cattle, Juiz de Fora - MG, for analysis of fat, protein, lactose, total solids (TS), non-fat dry extract (NFDE) and somatic cell count (SCC) using methods described by the International Dairy Federation (IDF, 2006).

Analyses on the composition was made by absorption spectrometry method using infrared $2000^{\circledR}$ Bentley (BENTLEY, 1995a). The SCC was analyzed by flow cytometry using the Somacount $300^{\circledR}$ equipment (BENTLEY, 1995b).

The electrical conductivity of milk was measured using the $\mathrm{Akso}^{\circledR} \mathrm{AK} 83$ model Portable Conductivity Electric Meter, and a standard calibration solution of $1413 \mu \mathrm{S} / \mathrm{cm}$, as recommended by the manufacturer. After the calibration of the solution followed by the measurement of conductivity, each sample was homogenized. The equipment has an electrode and when it is put into contact with the sample, it displays the value of the electrical conductivity $(\mathrm{mS} / \mathrm{cm})$ in its digital display.

The effects of breed, SCC and ECM were examined for statistical analysis. For SCC, the following categories were determined: 1 (to 600 thousand $/ \mathrm{mL}$ ) and 2 (greater than 600 thousand/ $\mathrm{mL}$ ). For ECM the categories were: 1 (less than 4.5 $\mathrm{mS} / \mathrm{cm}$ ) and 2 (greater than $4.5 \mathrm{mS} / \mathrm{cm}$ ). Data were subjected to analysis of variance. The differences between the averages of treatments were compared for independent samples using the Duncan test at 
5\% probability for SCC x Composition and ECM $\mathrm{x}$ composition. Statistical analyzes were performed using the Statistical Analysis System software (SAS, 2002).

Correlations between SCC and ECM variables were determined after separating the breeds by ECM with the composition and the SCC with the composition (fat, protein, lactose, total solids and non-fat dry extract).

\section{Results and Discussion}

The mean and standard deviation of milk composition, somatic cell count (SCC) and electrical conductivity milk (ECM) are in Table 1. The average values of SCC for the Gyr and Guzerat were 1629 and 1356 thousand cells $/ \mathrm{mL}$.

Table 1. Mean, standard deviation, maximum and minimum values found for the ECM variables $(\mathrm{mS} / \mathrm{cm}), \mathrm{SCC}$ (thousand cells/mL), FAT (\%), PROT (\%), LACT (\%), TS (\%) and NFDE (\%), in both Zebu breeds.

\begin{tabular}{cccccc}
\hline \multicolumn{7}{c}{ Gyr } \\
\hline Variable & $\mathbf{N}^{\mathbf{0}}$ of samples & Average & Standard Deviation & Minimum & Maximum \\
\hline ECM & 23 & 3.88 & 1.18 & 1.83 & 6.6 \\
SCC & 22 & 1629 & 2195 & 96 & 8907 \\
FAT & 22 & 4.71 & 1.77 & 2.26 & 11.1 \\
PROT & 22 & 3.29 & 0.31 & 2.83 & 4.24 \\
LACT & 22 & 4.5 & 0.33 & 3.66 & 4.85 \\
TS & 22 & 13.5 & 1.78 & 10.6 & 19.4 \\
NFDE & 22 & 8.79 & 0.37 & 8.04 & 9.73 \\
\hline & & \multicolumn{5}{c}{ Guzerat } & Maximum \\
\hline Variable & $\mathbf{N}^{\mathbf{0}}$ of samples & Average & Standard Deviation & Minimum & 5.74 \\
ECM & 42 & 3.59 & 0.88 & 2.18 & 6362 \\
SCC & 41 & 1356 & 1793 & 1 & 6.56 \\
FAT & 41 & 4.47 & 0.98 & 2.5 & 4.3 \\
PROT & 41 & 3.43 & 0.32 & 2.68 & 4.95 \\
LACT & 41 & 4.52 & 0.24 & 3.87 & 16.1 \\
TS & 41 & 13.5 & 1.19 & 11.2 & 9.96 \\
NFDE & 41 & 9.02 & 0.48 & 7.58 & \\
\hline
\end{tabular}

$\mathrm{ECM}=$ electrical conductivity of milk; $\mathrm{SCC}=$ somatic cell count; $\mathrm{PROT}=$ protein; $\mathrm{LACT}=$ lactose; $\mathrm{TS}=$ total solids; $\mathrm{NFDE}=$ non-fat dry extract.

The average of ECM found in this study was low in comparison with other studies showing a variation from 4.0 to $5.86 \mathrm{mS} / \mathrm{cm}$ for regular milk (NORBERG et al., 2004; YOSHIDA et al., 2005; ILIE et al., 2010). However, most of these studies conducted in Brazil and in other countries were conducted in cows of specialized breeds, mainly Hostein, while there is still little information in the literature on the ECM for Zebu cows.
Another factor that has an important influence on the ECM is the fat content in milk. An increase in the milk's fat content is related to the decrease in the milk's ability to conduct electrical current as fat is a poor conductor and the increase in the lipid fraction of milk results in an inhibiting ECM effect; not only by reducing the total conductive medium but, also by the physical obstacle that the fat globules offer to the migration of ions. It is also important to note 
that within the breed parameter, the zebu cows have a higher fat content in milk compared to Holstein cows and their crosses (MABROOK; PETTY 2003; ZAFALON et al., 2005; BARBOSA et al., 2008; KAŞIKÇI et al., 2012).

In research conducted by Mabrook and Petty (2003), they found ECM values of 5.05; 5.23; 5.40 and $4.85 \mathrm{mS} / \mathrm{cm}$ for the whole processed milk $(3.6 \%$ fat), semi-skimmed milk (1.6\% fat), skimmed milk $(0.1 \%$ fat $)$ and raw milk (3.6\% fat), respectively, each with a standard deviation of $0.3 \mathrm{mS} / \mathrm{cm}$. According to the researchers, the whole milk had a higher conductivity compared to raw milk due to the reduction in the size of the milk fat globules occurring during processing, thereby determining that the higher the fat content, the lower the ECM, which may explain the results of this work.

The average values of SCC for the Gyr and Guzerat were 1629 and 1356 thousand cells/mL respectively, were considered high values according to IN 62 (BRASIL, 2011), which recommends maximum values for healthy cows at 600,000 cells/ $\mathrm{mL}$. Factors that may have an indirect effect on the SCC are: the season, the stage of lactation and age of the cow. The SCC increases are observed as the age of the cow and the lactation stage advance to a greater cellular response function of adult cows, increased prevalence of infections and residual lesions from previous infections. Note the large increase in SCC after delivery and normal levels return only about 8-14 days later. An increase in SCC can also be observed before drying, when the milk production falls below $4 \mathrm{~kg} /$ day. However, both age and stage of lactation do not affect SCC in non-infected cattle, since the SCC increase observed in late lactation is associated with higher likelihood of the animal having been infected throughout lactation and to the extent they get older (RANGEL et al., 2011).

In addition to these factors, differences in the SCC can also be in response to the handling properties, since the environment has a great influence on this characteristic. The high milk SCC indicates the health of the mammary glands of cows and indicates significant loss of production and changes in the quality of milk (RUEGG et al., 2005; RUEGG, 2011; RANGEL et al., 2013; CICCONIHOGAN et al., 2013).

The Table 2 presents the averages of the physicochemical composition in relation to ECM and SCC. When analyzing the electrical conductivity of milk (ECM), it is observed that the constituents showed no significant differences for Gyr, although for Guzerat there was a significant difference for lactose.

The average of the constituents of fat, protein, lactose, total solids and non-fat dry extracts are within the range recommended by the literature for Zebu breeds with milk aptitude (RANGEL et al., 2009; GALVÃO JÚNIOR et al., 2010; RANGEL et al., 2014).

When analyzing the electrical conductivity of milk (ECM), it is observed that the constituents showed no significant differences for Gyr, although for Guzerat there was a significant difference for lactose; where there was an increase of ECM, lactose decreased. When analyzing the somatic cell count (SCC), there were significant differences in protein levels which decreased with lower levels of SCC and lactose decreased in proportion to the increase of SCC in Gyr breed. As for the Guzerá breed, fat and total solids were lower with low levels of SCC.

By analyzing the behavior of ECM in relation to milk constituents of the Guzerá cows, it was found that the lactose component fluctuated when the ECM level was above $4.5 \mathrm{mS} / \mathrm{cm}$ (Table 2). This was probably due to damage in the mammary gland (tissue damage), as inflammation of the mammary gland reduces the capacity for synthesis of glandular epithelium, thus reducing the lactose content and increases the passage of blood to the milk serum proteins, albumin, sodium and chlorine (AKERS; NICKERSON, 2011; BALLOU, 2012). 
Table 2. Average estimated milk composition within categories for electrical conductivity of milk (ECM) and somatic cell count (SCC) in Gyr and Guzerat breeds.

\begin{tabular}{cccccc}
\hline & \multicolumn{2}{c}{ Gyr } & & & \\
\hline & FAT & PROT & LACT & TS & NFDE \\
ECM Category (mS/cm) & & & & & \\
Up to 4.5 & $5.10^{\mathrm{a}}$ & $3.30^{\mathrm{a}}$ & $4.44^{\mathrm{a}}$ & $13.8^{\mathrm{a}}$ & $8.74^{\mathrm{a}}$ \\
Over 4.5 & $4.03^{\mathrm{a}}$ & $3.26^{\mathrm{a}}$ & $4.60^{\mathrm{a}}$ & $13.0^{\mathrm{a}}$ & $8.88^{\mathrm{a}}$ \\
SCC Category (1000cells/mL) & & & & & \\
Under 600 & $4.40^{\mathrm{a}}$ & $3.12^{\mathrm{b}}$ & $4.66^{\mathrm{a}}$ & $13.2^{\mathrm{a}}$ & $8.79^{\mathrm{a}}$ \\
Over 600 & $5.07^{\mathrm{a}}$ & $3.49^{\mathrm{a}}$ & $4.31^{\mathrm{b}}$ & $13.9^{\mathrm{a}}$ & $8.80^{\mathrm{a}}$ \\
\hline & & Guzerat & & & \\
\hline ECM Category (mS/cm) & FAT & PROT & LACT & TS & NFDE \\
Up to 4.5 & & & & & \\
Over 4.5 & $4.38^{\mathrm{a}}$ & $3.40^{\mathrm{a}}$ & $4.56^{\mathrm{a}}$ & $13.4^{\mathrm{a}}$ & $9.03^{\mathrm{a}}$ \\
SCC Category (1000cells $/ \mathbf{m L})$ & $4.93^{\mathrm{a}}$ & $3.57^{\mathrm{a}}$ & $4.33^{\mathrm{b}}$ & $13.9^{\mathrm{a}}$ & $8.97^{\mathrm{a}}$ \\
Under 600 & & & & & \\
Over 600 & $3.96^{\mathrm{b}}$ & $3.34^{\mathrm{a}}$ & $4.59^{\mathrm{a}}$ & $12.9^{\mathrm{b}}$ & $8.98^{\mathrm{a}}$ \\
\hline & $4.91^{\mathrm{a}}$ & $3.51^{\mathrm{a}}$ & $4.46^{\mathrm{a}}$ & $14.0^{\mathrm{a}}$ & $9.05^{\mathrm{a}}$ \\
\hline
\end{tabular}

Means followed by different capital letters in columns differ by Duncan test $(\mathrm{P}<0.05)$ / For ECM: 1 Up to $4.5 \mathrm{mS} / \mathrm{cm}$; 2 - Over 4.5 $\mathrm{mS} / \mathrm{cm}$ / SCC: 1 - Up to 600,000/mL; 2 - Over 600,000/mL. ECM = electrical conductivity of milk; SCC = somatic cell count; PROT $=$ protein; LACT $=$ lactose $;$ TS $=$ total solids; NFDE $=$ non-fat dry extract.

Lactose controls the volume of milk produced by attracting water from the blood to balance the osmotic pressure in the mammary gland. The lactose concentrations reduce when there is an increase in the concentration of $\mathrm{Na}^{+}$and $\mathrm{Cl}^{-}$to maintain the osmotic pressure in the milk (GONZALEZ et al., 2003), also confirmed in this work.

Also observed in association with increased SCC was a downward trend in the percentage of lactose for Gyr (Table 2), which can be explained by the fact that when the animal is afflicted with mastitis (a disease which is detected by an increase in SCC), there is a lower capacity to synthesize this component in infected mammary glands since it causes damage to the Golgi apparatus and secretory epithelial cells in the alveoli of the mammary gland (where the lactose is synthesized), resulting in a decrease in the biosynthesis of the constituent (LIMA et al., 2006).

As a result of the decrease in lactose synthesis and secretion, there is a decrease in milk production, where according to Gonzalez et al. (2003), the water content in the milk (on average $87 \%$ in the cow) depends on lactose synthesis since in the synthesis process the lactose "draws" water for mammary epithelial cells, meaning it is the main component with osmotic capacity in milk.

According to Ruegg (2011), the SCC increase causes changes in concentrations beyond lactose, fat and protein due to damage in the epithelial cells and increased vascular permeability.

In the present study, it was observed that the SCC also exerted influence on protein constituents for Gyr cows, and fat and total solids for Guzerat, where these components decreased to levels below 600,000 cells $/ \mathrm{mL}$. This can be explained by the fact that in cows with mastitis, there is an increase in protein concentrations because of the reduction of capacity for synthesis and casein secretion due to the damage caused in the secretory epithelium by 
bacterial toxins, which is also corroborated by this study. According to Akers and Nickerson (2011), as a result of the increase in SCC there is an increase in the concentration of serum proteins and a reduction of protein synthesized by the gland; this is undesirable because the protein is responsible for clotting milk, and the resulting yield production is casein derivative which is being synthesized by the gland.

Regarding the fat, there was a significant difference where SCC decreased, fat also decreased. There was also an increase in average total solids which can be explained by the increase in fat and protein as part of the construction of total solids (VARGAS et al., 2014).

All the averages involving the categories for ECM and SCC with the other constituents were significant when considering the two breeds (Table 3 ). However, most of the correlations were of low to medium magnitude. There was no significant correlation between ECM and SCC variables, but there was significant correlation between the constituents, which is in contrast to the literature since there is no information on this fact; there was always correlation between ECM and SCC.

Table 3. Linear correlation coefficients according to the Pearson model among the variables: electrical conductivity of milk (ECM), somatic cell count (SCC), fat (FAT), protein (PROT), lactose (LACT), total solids (TS) and non-fat dry extract (NFDE) in Gyr and Guzerat dairy cows.

\begin{tabular}{|c|c|c|c|c|c|c|c|}
\hline \multicolumn{8}{|c|}{ Gyr } \\
\hline & ECM & SCC & FAT & PROT & LACT & TS & NFDE \\
\hline ECM & 1 & 0.13 & -0.36 & -0.03 & 0.20 & -0.32 & 0.17 \\
\hline $\mathrm{SCC}$ & & 1 & 0.09 & $0.45^{*}$ & $-0.76^{*}$ & 0.00 & -0.40 \\
\hline FAT & & & 1 & 0.02 & -0.25 & $0.98^{*}$ & -0.10 \\
\hline PROT & & & & 1 & $-0.47 *$ & 0.10 & 0.37 \\
\hline LACT & & & & & 1 & -0.12 & $0.63^{*}$ \\
\hline TS & & & & & & 1 & 0.11 \\
\hline NFDE & & & & & & & 1 \\
\hline \multicolumn{8}{|c|}{ Guzerat } \\
\hline & ECM & SCC & FAT & PROT & LACT & TS & NFDE \\
\hline ECM & 1 & 0.18 & 0.21 & 0.19 & $-0.37 *$ & 0.16 & -0.04 \\
\hline SCC & & 1 & $0.49 *$ & 0.27 & -0.26 & $0.43^{*}$ & 0.07 \\
\hline FAT & & & 1 & $0.44 *$ & -0.26 & $0.92 *$ & 0.25 \\
\hline PROT & & & & 1 & 0.11 & $0.68 *$ & 0.78 \\
\hline LACT & & & & & 1 & 0.05 & 0.66 \\
\hline TS & & & & & & 1 & 0.61 \\
\hline NFDE & & & & & & & 1 \\
\hline
\end{tabular}

The original data were processed using the SCC $\log 10$; * Significant at the $1 \%$ level of probability; ECM = electrical conductivity of milk; SCC = somatic cell count; PROT = protein; LACT = lactose; TS = total solids; NFDE = non-fat dry extract. 
In the presence of mastitis, the potassium concentration in the milk decreases while the concentration of sodium ions and chloride increase conducting an increase in ECM. The test is based on the principle that the increased ECM is directly proportional to increased udder inflammation and increased SCC since there are changes in the ionic content of milk; where there is a decrease in potassium concentration, and concentrations of sodium ions and chloride go up due to increased permeability of blood capillaries and the destruction of the ion pump systems (NIELEN et al., 1992; RYSANEK; BABAK, 2005).

Unlike the results of this study, Juozaitienè et al. (2010) found positive and statistically significant correlations between SCC in milk and the ECM. Studies by Janzekovic et al. (2009) also reported a statistically positive relationship between SCC and the ECM for all udder quarts ranging from 0.27 to 0.46 .

\section{Conclusions}

The electrical conductivity of Gyr and Guzerat cow's milk show averages of $3.88 \mathrm{mS} / \mathrm{cm}$ and 3.59 $\mathrm{mS} / \mathrm{cm}$, respectively. The lactose levels of Guzerat cow's milk reduce according to the increasing electrical conductivity. There is no significant correlation between the electrical conductivity of milk and the somatic cell count.

\section{References}

AKERS, R. M.; NICKERSON, S. C. Mastitis and its impact on structure and function in the ruminant mammary gland. Journal of Mammary Gland Biology and Neoplasia, Bethesda, v. 16, n. 4, p. 275-289, 2011.

BALLOU, M. A. Inflammation: role in the etiology and pathophysiology of clinical mastitis in dairy cows. Journal of Animal Science, Champaign, v. 90, n. 5, p. 1466-1478, 2012.

BARBANO, D. M.; MA, Y.; SANTOS, M. V. Influence of raw milk quality on fluid milk shelf life. Journal of Dairy Science, Champaign, v. 89, p. 15-19, 2006. Supplement 1.
BARBOSA, S. B.; RAMALHO, R. P.; MONARDES, H. G.; DIAS, F. M.; SANTOS, D. C. D.; BATISTA, A. Milk and fat production of crossbred Holstein-Gir cows (Bos taurus taurus-Bos taurus indicus) in the Agreste region of the Brazilian state of Pernambuco. Genetics and Molecular Biology, Ribeirão Preto, v. 31, n. 2, p. 468474, 2008.

BAVA, L.; ZUCALI, M.; SANDRUCCI, A.; BRASCA, M.; VANONI, L.; ZANINI, L.; TAMBURINI, A. Effect of cleaning procedure and hygienic condition of milking equipment on bacterial count of bulk tank milk. Journal of Dairy Research, Cambridge, v. 78, n. 2, p. 211-219, 2011.

BENTLEY Instruments. BENTLEY 2000 Operator's Manual. Chaska: Hach Company, 1995a. 77 p.

Somacount 2000 Operator's Manual. Chaska: Hach Company, 1995b. 12 p.

BRASIL. Ministério da Agricultura, Pecuária e Abastecimento. Instrução Normativa $n^{\circ} 62$, de 29 de dezembro de 2011. Diário Oficial [da] União, n 251, Brasília, 2011, Seção 1, p. 6-11.

CICCONI-HOGAN, K. M.; GAMROTH, M.; RICHERT, R.; RUEGG, P. L.; STIGLBAUER, K. E.; SCHUKKEN, Y. H. Associations of risk factors with somatic cell count in bulk tank milk on organic and conventional dairy farms in the United States. Journal of Dairy Science, Champaign, v. 96, n. 3, p. 3689-3702, 2013.

FOSGATE, G. T.; PETZER, I. M.; KARZIS, J. Sensitivity and specificity of a hand-held milk electrical conductivity meter compared to the California mastitis test for mastitis in dairy cattle. The Veterinary Journal, Amsterdam, v. 196, n. 1, p. 98-102, 2013.

GALVÃO JÚNIOR, J. G. B.; RANGEL, A. H. N.; MEDEIROS, H. R.; SILVA, J. B. A.; AGUIAR, E. M.; MADRUGA, R. C.; LIMA JÚNIOR, D. M. Efeito da produção diária e da ordem de parto na composição físico-química do leite de vacas de raças zebuínas. Acta Veterinaria Brasilica, Mossoró, v. 4, n. 1, p. 25-30, 2010.

GONZALEZ, S. G.; MÜLLER, E. E.; RIBEIRO, E. L. A.; FREITAS, J. C.; GODOY, A. L. Influência de fatores raciais e manejo nutricional na contagem de células somáticas e nos constituintes do leite de vacas holandesas e mestiças no Norte do Estado do Paraná, Brasil. Acta Scientiarum. Animal Sciences, Maringá, v. 25, n. 2, p. 323-329, 2003.

ILIE, L. I.; TUDOR, L.; GALIS, A. M. The electrical conductivity of cattle milk and the possibility of mastitis diagnosis in Romania. Lucrări Stiintifice Medicină Veterinară, Iasi, v. 43, n. 2, p. 220-227, 2010. 
INTERNATIONAL DAIRY FEDERATION - IDF. Whole milk determination of milkfat, protein and lactose content. Guide fir the operation of mid-infrared instuments. Bruxelas: IDF/FIDL, 2006. 12 p. (IDF Standard 141 B).

JANZEKOVIC, M.; BRUS, M.; MURSEC, B.; VINIS, P.; STAJNKO, D.; CUS, F. Mastitis detection based on electric conductivity of milk. Journal of Achievements in Materials and Manufacturing Engineering, Philadelphia, v. 34, n. 1, p. 39-46, 2009.

JUOZAITIENEE, V.; ŠLAPKAUSKAITĖ，J.; TUŠAS, S.; BRAZAUSKAS, A.; JAPERTIENE, R. Electrical conductivity changes of milk during milking phase with cows productivity and somatic cells count. Veterinarija Ir Zootechnika, Kaunas, v. 51, n. 73, p. 23-29, 2010.

KAŞIKÇI, G.; ÇETIN, Ö.; BİNGÖL, E. B.; GÜNDÜZ, M. C. Relations between electrical conductivity, somatic cell count, California mastitis test and some quality parameters in the diagnosis of subclinical mastitis in dairy cows. Turkish Journal of Veterinary \& Animal Sciences, Ancara, v. 36, n. 1, p. 49-55, 2012.

LANGONI, H. Qualidade do leite: utopia sem um programa sério de monitoramento da ocorrência de mastite bovina. Pesquisa Veterinária Brasileira, Seropédica, v. 33, n. 5, p. 620-626, 2013.

LANGONI, H.; PENACHIO, D. D. S.; CITADELLA, J. C.; LAURINO, F.; FACCIOLI-MARTINS, P. Y.; LUCHEIS, S. B.; SILVA, A. V. D. Aspectos microbiológicos e de qualidade do leite bovino. Pesquisa Veterinária Brasileira, Seropédica, v. 31, n. 12, p. 10591065, 2011.

LIMA, M. C. G.; SENA, M. J.; MOTA, R. A.; MENDES, E. S.; ALMEIDA, C. C.; SILVA, R. P. P. E. Contagem de células somáticas e análises físico-químicas e microbiológicas do leite cru tipo $\mathrm{C}$ produzido na região Agreste do Estado de Pernambuco. Arquivos do Instituto Biológico, São Paulo, v. 73, n. 1, p. 89-95, 2006.

MABROOK, M. F.; PETTY, M. C. Effect of composition on the electrical conductance of milk. Journal of Food Engineering, Amsterdam, v. 60, n. 3, p. 321-325, 2003.

NIELEN, M.; DELUYKER, H.; SCHUKKEN, Y. H.; BRAND, A. Electrical conductivity of milk: measurement, modifiers, and meta analysis of mastitis detection performance. Journal of Dairy Science, Champaign, v. 75, n. 2, p. 606-614, 1992.

NORBERG, E. Electrical conductivity of milk as a phenotypic and genetic indicator of bovine mastitis: a review. Livestock Production Science, Wellington, v. 96, n. 2, p. 129-139, 2005.
NORBERG, E.; ROGERS, G. W.; GOODLING, R. C.; COOPER, J. B.; MADSEN, P. Genetic parameters for test-day electrical conductivity of milk for first lactation cows from random regression models. Journal of Dairy Science, Champaign, v. 87, n. 6, p. 1917-1924, 2004.

RAIMONDO, R. F. S.; BRANDESPIM, F. B.; PRINA, A. P. M.; BIRGEL JÚNIOR, E. H. Avaliação do pH e da eletrocondutividade do leite de bovinos da raça Jersey durante o primeiro mês de lactação. Semina: Ciências Agrárias, Londrina, v. 30, n. 2, p. 447-456, 2009.

RANGEL, A. H. N.; ARAÚJO, T. P. M.; MEDEIROS, H. R.; LIMA JÚNIOR, D. M.; ANDRADE, K. D.; MADRUGA, R. C.; BEZERRIL, R. F.; NOVAES, L. P. Body condition score (BCS) and calving order on milk production and composition in zebu cattle. Acta Veterinaria Brasilica, Mossoró, v. 8, n. 4, p. 247-253, 2014.

RANGEL, A. H. N.; ARAÚJO, V. M.; BEZERRA, K. C.; BARRETO, M. L. J.; MEDEIROS, H. R.; LIMA JÚNIOR, D. M. Avaliação da qualidade do leite cru com base na contagem de células somáticas em rebanhos bovinos comerciais no estado do Rio Grande do Norte, Brasil. Archives of Veterinary Science, Curitiba, v. 18, n. 1, p. 40-45, 2013.

RANGEL, A. H. N.; MEDEIROS, H. R.; SILVA, J. B. A.; BARRETO, M. L. J.; LIMA JÚNIOR, D. M. Correlação entre a contagem de células somáticas (CCS) e o teor de gordura, proteína, lactose e extrato seco desengordurado do leite. Revista Verde de Agroecologia e Desenvolvimento Sustentável, Mossoró, v. 4, n. 3, p. 57-60, 2009.

RANGEL, A. H. N.; OLIVEIRA, J. P. F.; ARAÚJO, V. M.; BEZERRA, K. C.; MEDEIROS, H. R.; LIMA JÚNIOR, D. M.; OLIVEIRA, C. G. F. Influência do estádio de lactação sobre a composição do leite de búfalas. Acta Veterinaria Brasilica, Mossoró, v. 5, n. 3, p. 306-310, 2011.

RIBEIRO NETO, A. C.; BARBOSA, S. B. P.; JATOBÁ, R. B.; SILVA, A. M.; SILVA, C. X.; SILVA, M. J. A.; SANTORO, K. R. Qualidade do leite cru refrigerado sob inspeção federal na região Nordeste. Arquivo Brasileiro de Medicina Veterinária e Zootecnia, Lavras, v. 64, n. 5, p. 1343-1351, 2012.

RUEGG, P. L. Managing mastitis and producing high quality milk. In: RISCO, C.; MELENDEZ, P. (Ed.). Dairy cattle production medicine. Ames: Wiley-Blackwell Publishing Ltd, 2011. p. 207-232.

RUEGG, P. L.; HULLAND, C.; RIETH, B. Performance of the direct cell counter used on milk samples obtained from fresh cows. In: NATIONAL MASTITIS COUNCIL 
ANNUAL MEETING, 44., 2005, Orlando. Proceedings... Orlando: National Mastitis Council, 2005. p. 291-292.

RYSANEK, D.; BABAK, V. Bulk tank milk somatic cell count as an indicator of the hygiene status of primary milk production. Journal of Dairy Research, Cambridge, v. 72, n. 4, p. 400-405, 2005.

STATISTICAL ANALYSIS SYSTEM - SAS Institute®. User's guide: statistics. Version 9.1. $4^{\text {th }}$ ed. Cary: SAS Institute, 2002.

SHARMA, N.; SINGH, N. K.; BHADWAL, M. S. Relationship of somatic cell count and mastitis: an overwiew. Asian-Australasian Journal of Animal Science, Seoul, v. 24, n. 3, p. 429-438, 2011.

UHLER, C. Mastitis in dairy production: estimation of sensitivity, specificity and disease prevalence in the absence of a gold standard. Journal of Agricultural, Biological, and Environmental Statistics, Champaign, v. 4, n. 1, p. 79-98, 2009.
VARGAS，D. P.; NÖRNBERG，J. L.; MELLO，R O.; SHEIBLER, R. B.; BREDA, F. C.; MILANI, M. P. Correlações entre contagem de células somáticas e parâmetros físico-químicos e microbiológicos de qualidade do leite. Ciência Animal Brasileira, Goiânia, v. 15, n. 4, p. 473-483, 2014.

YOSHIDA, T.; LOPEZ-VILLALOBOS, N.; HOLMES, C.W. Relationships between milk yield, milk composition and electrical conductivity in dairy cattle. Proceedings of the New Zealand Society of Animal Production, Auckland, v. 65, n. 1, p. 143-147, 2005.

ZAFALON, L. F.; NADER FILHO, A.; OLIVEIRA, J. V.; RESENDE, F. D. D. Comportamento da condutividade elétrica e do conteúdo de cloretos do leite como métodos auxiliares de diagnóstico na mamite subclínica bovina. Pesquisa Veterinária Brasileira, Seropédica, v. 25, n. 3, p. 159-163, 2005. 